\title{
THE SPECIFICITY OF THE INVESTMENT IN LAND AS IN REAL ESTATE
}

\author{
Rita REMEIKIENE $\dot{1}^{1,}$, Ligita GASPARENIENE ${ }^{1}$, Romualdas GINEVIČIUS ${ }^{2}$ \\ ${ }^{1}$ Lithuanian Institute of Agrarian Economics, V. Kudirkos 18-2, 03105 Vilnius, Lithuania \\ ${ }^{2}$ Vilnius Gediminas Technical University, Sauletekio av. 11, 10223 Vilnius, Lithuania
}

Received 31 March 2018; accepted 17 September 2018

\begin{abstract}
The main purpose of this article is to identify the motives of investing in land and arable land and determine the choices of such investment. The empirical research, based on the method of expert evaluation, fills the gap of the investment in land observed in scientific literature. The expert evaluation has allowed to develop a profile of a land investor, identify the determinants of the value of land and arable land and clarify the motives of investing in land in a small open economy (the trends in one small economy may reflect similar trends in other small open economies, for instance, Latvia or Estonia). The novelty of the article lies in the disclosure of the general and Lithuania-inherent land investment risks and assessment of the impact of the main land value determinants. The practical implications of the article lie in submission of the guidelines to real estate policy and practice makers, investors, real estate developers, buyers and other parties concerned that want to get a better understanding of the expediency or inexpediency of the investment in land.
\end{abstract}

Keywords: land investment, real estate, land value, general determinants, microeconomic determinants.

\section{Introduction}

Investment in real estate is a growing investment area, selected by investors with the aim to diversify their investment portfolios and protect them from unexpected and unwanted value fluctuations. As real estate plays one of the most important roles in general economics, the methods and mechanisms of real estate funding are thoroughly analysed at European and global levels. The recent financial recession forced to look for the ways to reduce welfare costs: states cut down on their investment in public infrastructures (roads, renovation of buildings, etc.). Real estate markets are increasingly considered to be beneficial and able to flexibly and effectively meet consumer needs, this way promoting the recovery of national economies.

The current trends of land grabbing call for the need to comprehensively research land investment expediency, trends. Although scientific literature is rich in the studies to focus on the issues of real estate development (the development of international and local real estate markets was analysed by Wyman, Seldin, and Worzala (2011), Tiwari and White (2014), Hin, Ho, and Addae-Dapaah (2014), Faulkner (2016), Dong and Sing (2017), etc.; the dynamics of the investment in real estate were studied by Gholipour Fereidouni and Masron (2013), Patterson (2013), French (2015), etc.; the impact of the global financial crisis on real estate prices was researched by van der Heijden, Dol, and Oxley (2011), Hegedüs, Lux, and Sunega (2011), Scanlon and Elsinga (2014), etc.; real estate funding forms were addressed by Kemp (2007), Griggs and Kemp (2012), Squires et al. (2016), etc.; the impact of tax policies on real estate possession was analysed by Oxley and Haffner (2010), Figari et al. (2012), etc.) investment in land thus far have earned insufficient scientific attention, especially at the national level.

The novelty of this article lies in the comprehensive analysis of the opportunities to invest in land in the global and local contexts, identification of the theoretical and practical motives to invest in land, identification of the general risks and the risks faced by Lithuanian land investors, and assessment of the factors that have the most significant impact on the value of land. Previous land studies mainly focused on the logic of the general investment in land (Knuth, 2015), investment in argicultural land (Gunnoe \& Gellert, 2011; Gunnoe, 2014), and the role of financial institutions in land funding (Bergdolt \& Mittal, 2012; Buxton, Campanale, \& Cotula, 2012). Nevertheless, the investment in land as in a specific type of real estate is hardly analysed. This gap in the scientific literature proposes the following scientific problem:

${ }^{*}$ Corresponding author. E-mails: rita.remeikiene@laei.lt 
is investment in land expedient and what are the opportunities to invest in land?

The purpose of this article is to identify the motives of investing in land and arable land and determine the choices of such investment. For fulfilment of the defined purpose, the following objectives were raised: 1 ) to review the theoretical peculiarities of land investment; 2) to select and introduce the methodology of the research; 3) to empirically assess land investment problems and opportunities.

The methods of the research include systematic and comparative literature analysis, and expert evaluation.

The practical implications of the article lie in submission of the guidelines to real estate policy and practice makers, investors, real estate developers, buyers and other parties concerned that want to get a better understanding of the expediency or inexpediency of the investment in land.

The limitations of the findings are linked to the lack of the experts who can objectively assess land-related investment decisions as well as to the narrowness of the mathematical-statistical estimations as the statistical databases available for data extraction contained the data on the prices of arable land (eur/ha) for the period not earlier than 2011.

\section{Review of the theoretical peculiarities of land investment}

The recent changes in land usage have earned much attention in the discussions of global environment and economics. Although real estate is described as an immovable property, such as land and its permanents attachments (e.g. buildings), land differs from other kinds of real estate because it can serve as an independent object of investment even without related infrastructures, while other kinds of real estate (e.g., commercial and trade premises, housing) are always related to land.

The discussions about land often cover the issue of what the term "vacant land" actually refers to. It should be noted that vacant land is not the same as raw land as the latter refers to the land which has not been affected by human activities. Vacant land, on the contrary, is understood as raw land improved by human activities, but currently vacant (i.e. vacant land can possess different communications, utility infrastructures, roads, etc.) (Grant, 2016). Land investment commonly refers to the investment in vacant rather than raw land. In this case, the concept of land covers not only vacant land plots for construction purposes, but also arable land (Williams, 2013a).

Land possesses another economic characteristic, which distinguishes it from the other kinds of real estate: land usage is of a derivative nature, i.e. land can be used not only as an asset, but also as a capital necessary for a particular human economic activity (for instance, agriculture, production, consumption, investment, recreation, etc.) because any human activity requires a geographical location. Economic activities are projected to be carried out in a particular geographical area, in which real estate may gain different forms subject to the planned or already performed economic functions (e.g., infrastructure, agriculture, green areas in cities, etc.).

As land is a scarce resource, its supply is limited. With reference to the World Bank (2018), over the period 1961 to 2015, the share of arable land (in hectares) per capita decreased from 0.371 to 0.194 at the global scale. While assessing the situation in Lithuania, it should be noted that till 1992, i.e. till restoration of the country's independence, the statistical data on land or its usage were not accumulated. During the period from 1992-2015, the share of land per capita in the country decreased only insignificantly: from 0.78 to 0.748 hectares. In spite of the fact that the situation in Lithuania is comparatively stable, the global statistics show that the percentage change in the number of population is much faster than the percentage change in land availability. As a result, the further growth in the number of population (with reference to the estimates of the United Nations, the word's population will number nearly 10 billion in 2083 (Rosenberg, 2017)) is going to determine even greater scarcity of land resources and land price surges in real estate markets. The global land price growth tendencies may as well as cause an increase in land prices in Lithuanian real estate market.

The changes in land usage are always determined by the trends of economic development. The historical experience contains the examples of the progressive raw land transformation into agricultural, urbanistic or industrial territories. The transformations of this type are conditioned by such socio-economic factors, as the growth in the number of population, food production, income, wood production and recognition of land ownership.

Knuth (2015) describes the interest in land as land ownership-related rights, responsibilities and restrictions. Land cadastres usually hold such data as geometrical descriptions of land plots, ownership interests, control, land plot value and possible improvements (Enemark, 2001).

The main feature, which distinguishes land from other types of real estate, is independency of land as of an investment object because land is not dependent on related objects (e.g. buildings), while the latter are always dependent on land. In addition, land is characterised by the derivative nature of its usage, when the demand for land is determined by the need of a geographic area for human economic activities and by land's scarcity. Land value is determined by the real economic and physical usage of land and land-related property. The opportunities to use land in the future also affect (in this case, it depends on land usage policies and planning regulations) the value of land. Efficiently functioning land management and land value systems help to create an effective land market, while efficient land usage and land development systems contribute to the effective land usage management. As the demand for land as for a capital asset and natural resource is not going to decrease in the future, land investment and 
land investment funding are becoming increasingly topical issues nowadays.

Investment in land has historically been the basis of asset accumulation for large companies, farmers and other well-off people. It is treated as a long-term investment. When land prices are rising, land investment is said to be the safest and most reasonable way to invest free money (Williams, 2013b). Land investment can also be profitable when land supply is limited. However, the real value of land investment depends on investment-related risks, which means that land investment can turn out to be profitable when attractive business opportunities are envisaged, when an investor can earn income from rent, when land can be pledged for a loan, when land ownership can help to reduce the amount of taxable income or when an investor can earn profits from land resale. Even vacant land plots can generate sufficient cash flows. The analysis of the scientific literature has allowed to identify the main land investment motives (see Table 1).

The data in Table 1 show that the motives to invest in land are financial and non-financial. Apart from the duty to pay land and land-related taxes, a land owner hardly bears any other costs, unlike, for instance, an owner of a office building, who has to take a continuous care of the technical and representative state of the building, indoor and outdoor lighting, arrangement of parking lots, the greenery around the building, etc. (Williams, 2013b). What is more, land as an investment object does not require any improvements (Grant, 2016). As it was noted by Knuth (2015), Grant (2016) and others, the need of the initial capital for land investment is comparatively low, in particular when investment is made through modern funding mechanisms. Thus, an investor may use personal rather than borrowed funds. The land acquired by employing personal funds becomes an inexpensive long-term investment as an investor does not pay any interest for borrowed funds (Williams, 2013b).
Economics are sensitive to the cyclical changes of upturns and recessions. During the periods of an economic upturn, population's income in countries and regions is inclined to grow, which, in turn, leads to higher overall demand. Under these conditions, higher demands for commercial, industrial and other types of property determine the growth in the demand for land and a higher land value. Hence, it is financially benefitial to buy land during the periods of economic recessions and sell during the periods of economic upturns (Grant, 2016). Predictability of the value of land at different stages of an economic cycle distinguishes land from other types of financial investment (e.g. stock, precious metals, etc.), the value of which is often difficult to predict. Land investment can be distributed according to an expected growth in particular industries. For instance, anticipation of urban development may promt the investment in urban territories, while expectations of agricultural development - the investment in arable land. An investor may also choose the investment in forests, water bodies, etc. The land, located near welldeveloped regions, costs more than the land, located near under-developed or non-developed regions. The value of land for housing and commercial purposes also differs. Hence, the investment in land can be matched with the trends of sectoral development (Knuth, 2015).

While analysing the financial motives of land investment, Williams (2013b) notes that land investors have a strong motivation to sell land as they do have any close emotional connection with it. The author (Williams, 2013b) also states that the people who are strogly emotionally connected with land (e.g. live on it) never find "the right time" to sell it and occasionally look for the ways to optimize land usage, i.e. they are passive rather than active investors. Williams (2013b) and Grant (2016) highlight less intensive competition in the land market in comparison to the competition in the housing or commercial premises markets, i.e. the supply of housing or commercial premises is higher than the supply of land plots.

Table 1. Land investment motives

\begin{tabular}{|c|c|}
\hline Motives & Comments \\
\hline \multicolumn{2}{|l|}{ Financial motives } \\
\hline Low maintenance costs & Maintenance costs are limited to land and land-related taxes \\
\hline Low initial capitals & Land plots are cheaper than buildings \\
\hline $\begin{array}{l}\text { Prognosticated value changes in different } \\
\text { stages of an economic cycle }\end{array}$ & $\begin{array}{l}\text { During the periods of economic recession, land price decreases, while during the } \\
\text { periods of economic upturns land price increases }\end{array}$ \\
\hline Sectoral distribution of investment & The opportunities to invest in different purpose (urbanistic, arable, forest, etc.) land \\
\hline The way to diversify an investment portfolio & $\begin{array}{l}\text { The measure to diversify a long-term investment portfolio, when an investor can } \\
\text { earn from the future rise in land value }\end{array}$ \\
\hline \multicolumn{2}{|l|}{ Non-financial motives } \\
\hline Strong motivation to sell & Investors do not possess any emotional links with land \\
\hline Little competition & Supply in the land market is lower than in other real estate markets \\
\hline Asset safety & Land possesses such physical characteristics as immobility and indestructibility \\
\hline Asset's feature to retain its value & High value of land as of a scarce resource \\
\hline
\end{tabular}


As a result, investment in land is considered to be safer than investment in other types of real estate.

While analysing the risk of land investment, Williams (2013a) notes that an investor must understand what the land can be used for (e.g. construction of residential buildings, industrial complexes, infrastrusture, etc.) as only in this case the investment can be considered expedient. The expedience of land investment is often characterised by land's topography (i.e. exposure to landslides, avalanches, floods, etc.) as it can severy restrict building of infrastructures in a land plot and limit the scale of land usage ("zoning restrictions"). According to Eberlin (2017), the effects of "zoning restrictions" are similar to the effects of political, legal and ecological risks.

Grant (2016) highlights the importance of an agent risk. The author (Grant, 2016) speaks against acquisition of land from the agents who have owned a land plot for a comparatively short period of time, especially if an agent is a real estate developer or construction company. According to Grant (2016), the fact that an agent wants to sell land quickly, may actually mean that its value is low, lower than it is expected, land usage is likely to be restricted in the nearest future, etc. The similar risks can be borne when an investor is buying land for an unreasonably low price.

Land investment is always linked to particular financial risks, i.e. the investment in land can cause expenditure and losses. As land taxes occupy the largest share of land maintenance costs, constantly changing real estate taxation policies and increasing real estate taxes for domestic and foreign agents are the biggest sources of concern for land investors (Eberlin, 2017). The other important types of risk cover the risk of unfulfilled expectations, when an investor assesses the situation with consideration of past rather than future market trends (which, in turn, makes preconditions for real estate bubbles), and land overholding risk, when an investor fails to sell land on most favourable terms (Williams, 2013a).

The authors of this article support the opinion that land is a risky but an attractive investment. One of its advantages is that the quantity of this asset remains stable (i.e., land does not multiply). Land always has its value, which allows to estimate the return on this investment. Investors can choose the investment in land at both the lo$\mathrm{cal}$ and global levels. The main reasons that determine the investment in land at one of the above-mentioned levels include the conditions in the market, the differences in the return on investment, legal frameworks (presence or absence of land-investment favourable environment, etc.) and an expected rise in prices for speculative purposes. The prices of land plots can also be influenced by foreign investors who may increase the demand for land by buying land plots in a foreign country. At both the local and global levels liberalization of the trade in land is important not only because of the economic benefits gained by land owners and the rural population, but also due to the necessity to reform the current regulations which violate the principle of the respect for private property established in the Constitution. The reluctance to reform the restrictive regulations speaks about the distrust in the ability of citizens to manage their properties. The investment in arable land could be promoted by employing advanced technologies. In case no new participants enter the market, the current entities will hardly be able to meet the production quotas and requirements of the $\mathrm{EU}$, which will lead to the reduction of the $\mathrm{EU}$ funding.

Summarising, land investment not always generates constant benefits and not always pays off in short or medium terms, but it is likely to pay off in the long term. The main financial motives of land investment include low maintenance costs, low initial capital, prognosticated value changes in different stages of an economic cycle, sectoral distribution of investment and the opportunities of portfolio diversification. The risks of land investment are mainly linked to land's topography, "zoning restrictions", possible changes in land usage and instability of political, legal and ecological environment. The increase in land maintenance costs (in particular, the growth of land and real estate taxes), unfulfilled expectations (real estate bubbles), land overholding, cash flow changes and diseconomy of scale are the main types of land investment risk.

\section{Research methodology}

In order to implement the purpose of the research, the method of expert evaluation (interviews and a questionnaire survey) was employed. The experts of the real estate market were represented by:

- Marius Dubnikovas, who is currently in charge of Business Development Manager position at "Compensa Life Vienna Insurance Group SE", with more than 15 years of professional and practical experience in the areas of real estate valuation and finance. He started his career as the President of Lithuanian Financial Brokers Association, and subsequently followed the position of Client Investment Manager at "Finasta Ltd." The expert is also the Chairman of the Tax Committee, Lithuanian Business Confederation. The financial analyst is particularly active with his speeches and insights into the trends of the real estate market in media;

- Saulius Vagonis, who is the Head of Valuation and Analysis in "OBER-HAUS Real Estate Ltd.". He has acquired his experience in working with real estate for over 20 years. During the expert's career, more than 3000 asset evaluations and about 100 outsource market studies and analyses have been conducted. Saulius Vagonis is a board member of Lithuanian Association of Property Valuers and Lithuanian Association of Property and Business Valuation Enterprises, and the Chairman of the Commission on Science and Education. He actively participates in real estate conferences (e.g. Real Estate Conference 2016 and 2017, organized by the Bank of Lithuania); 
- Dr. Vytautas Azbainis, who has gained his experience in drawing up real estate investment projects and land plot detailed plans during 13 years of professional career. Since 2005 he has held the position of the director of "Vilniaus Namas Ltd." In 2014, he defended the dissertation "Real Estate Market Cycle Management and Modelling";

- Romualdas Paulauskas, who has accumulated more than 15 years of experience in the real estate sector. Currently, he is the Head of "OBER-HAUS Real Estate Ltd.", Panevėžys Department. His professional insights are published in popular Lithuanian newspapers "Verslo žinios", "Lietuvos rytas", "Vakarų ekspresas", etc.;

- Emilijus Gedvilas, who is a broker at "Akorus Real Estate". The expert has been purposefully working with land investment, purchase and sales of real estate, and the development of real estate objects for about 4 years.

The aim of expert evaluations is to obtain the data from a person who is considered an experienced professional in particular area. With reference to Makridakis, Wheelwright, and Hyndman (1998), in accordance with the objectives of a study and with consideration of the level of experts' competence, expert evaluation should involve from 10 to 100 experts. Meanwhile, according to Augustinaitis et al. (2009), in order to maintain the accuracy and reliability of expert evaluation, at least 5 experts should be involved (this recommendation was based on the findings of the empirical research). In this study, the focus falls on the competence rather than number of the experts involved. With reference to Augustinaitis' et al. (2009) recommendations, 5 experts were involved.

The logical sequence of the research was as follows:

1. Expert interviews with Marius Dubnikovas and Saulius Vagonis;

2. Questionnaire survey.

The expert interviews were employed with the aim to identify the main land investment motives and explain the trends of the land market. During the interviews, the experts were asked the following open-type questions:

- What are the main motives to invest in land as in real estate?
- What land price tendencies are predicted for the future and what reasons will determine the changes in the land market?

The questionnaire survey was employed with the aim to define land investment opportunities by focusing on land price determinants in Lithuania. On the basis of the survey results, the insights in land investment prospects in Lithuania were made.

The questionnaire, submitted to the experts, consisted of 3 parts. The first part was intended for creation of a profile of a land investor. The experts were provided with the questions concerning the characteristics of a subject, the level of risk tolerance and the channels of land investment (i.e. direct or indirect (through intermediaries) investment).

The second part was devoted to identification of land value determinants. The experts were asked to rank the general (interdependence of financial markets, economic, social, legal, political, demographical, institutional and construction factors) and microeconomic (an object's characteristics, environmental factors, the factors of an investor's behaviour) land price determinants by their importance at the Likert's scale. The third part of questionnaire was developed for the assessment of land investment tendencies in Lithuania. The systematized content of the questionnaire has been presented in Table 2 .

The data was processesed with SPSS and "Microsoft Excel" software. Reliability of the expert evaluations depends on the experts' knowledge and number. Assuming that the experts are sufficiently precise, it can be stated that a larger number of the experts involved increases reliability of the expertise. The degree of an expert's competence is valuated by employing the coefficient of competence. The special attention must be drawn to interpretation of the values of Cronbach alpha coefficient. Cronbach alpha coefficient indicates whether a questionnaire reflects the subject matter with sufficient accuracy. Some researchers, for instance, Nunnally and Bernstein (1994), argue that Cronbach alpha coefficient must not be lower than 0.7, while other researchers, for instance, Malhotra and Birks (2003), state that the lowest critical limit of a questionnaire's reliability is 0.6 . Hence, the choice of the lowest critical limit is a subjective matter which depends on the nature and qualitative aspects of a particular study.

Table 2. Relevance of the questions

\begin{tabular}{|l|l|l|}
\hline Questionnaire part & Questions/Statements & Relevance of the questions \\
\hline $\begin{array}{l}\text { Part 1. A profile of a land } \\
\text { investor }\end{array}$ & $\begin{array}{l}\text { Which subjects are most active land investors in } \\
\text { Lithuania? } \\
\text { What risk levels are assumed by land investors? } \\
\text { What are the most common ways of land } \\
\text { investment? }\end{array}$ & $\begin{array}{l}\text { Aim - a land investor's profile can help to } \\
\text { develop the appropriate measures (funding } \\
\text { sources, etc.) for attraction of investors to the } \\
\text { land market }\end{array}$ \\
\hline $\begin{array}{l}\text { Part 2. The determinants of the } \\
\text { value of land as of an investment } \\
\text { object }\end{array}$ & $\begin{array}{l}\text { Ranking of general determinants by their } \\
\text { importance } \\
\text { Ranking of microeconomic determinants by } \\
\text { their importance }\end{array}$ & $\begin{array}{l}\text { Aim - identification of the most influential } \\
\text { land value determinants may provide the } \\
\text { opportunities to recognise the signs indicating } \\
\text { plausible land price changes in the future }\end{array}$ \\
\hline
\end{tabular}




\section{The results of the empirical research}

In the first stage of the research, the experts Marius Dubnikovas and Saulius Vagonis were interviewed. Marius Dubnikovas submitted the following answer to the question "What are the main motives to invest in land as in real estate?":

1. Price increase in the land market. Land price trends in Western countries propose that the value of land in Lithuania should also increase. The period 20162017 saw growing prices of land plots in particular segments and locations. Leaning on the theory of expectations (i.e. on conviction that land prices are going to increase), real estate developers, investors and speculators cause land supply shrinkage, which, in turn, leads to a notable price growth and formation of positive expectations;

2. The intention to earn from the development of real estate. As housing (in particular, apartment) prices are growing up, the segment of individual houses and cottages (which due to high supply has hardly ever captured any price growth) is becoming increasingly attractive. Earning higher income, the population can afford to buy or build a higher-class housing, which, in turn, spotlights the segment of land plots (home ownerships);

3. As an investment object, land is a hedge against inflation because the value of arable land has historically been growing faster than inflation rate. Thus, arable land is treated as an effective hedge against inflation and a measure to preserve the value of capital.

The main motive of land investment is speculative, i.e. land is acquired with the aim to develop real estate projects/objects and earn from resales or price increase. The investment in arable land is basically made with the aim to rent it to farmers or build infrastructures for the development of particular businesses.

According to Saulius Vagonis, land investment motives depend on an investor's aims. The first motive is linked to the expectations of land price growth in the future. An investor often invests in land because land plot prices (especially, in suburbs and countrysides) are lower than housing or commercial premise prices. Another motive is passive investment: land does not require any regular maintenance, while many other types of real estate need it. If investors seek a stable return, they prefer investment in arable land, which ensures stable cash flows from rent. For earning of active income, investors choose land as a construction element, which allows to earn from the development of real estate projects.

Next, the experts submitted their answers to the question "What land price tendencies are predicted for the future and what reasons will determine the changes in the land market?"

As it was noted by Marius Dubnikovas, the future should see an increase in land prices, although land investment funding to a large extent depends on basic interest rates, the changes in which form land demand trends.
Saulius Vagonis expressed the opinion that the prices of arable land will largely depend on the EU support policies, while non-arable land plot prices will be determined by the general economic situation and the trends of urban development.

In the second stage of the research, the experts were asked to complete the questionnaire. While interpreting the results of the expert evalution, only the concepts and factors with mean ranks equal to or exceeding 3.5 were considered significant. The value of Cronbach alpha was equal to $0.98^{1}$, which confirmed that the questionnaire reflects the researched dimension with appropriate accuracy.

The results of the expert evaluation allowed to form a profile of a land investor: a typical land investor is a lowrisk assuming individual, business enterprise or household, commonly investing without intermediaries.

The general determinants of the value of land as of an investment object have been systematised in Table 3 (the determinants with mean ranks from 4 to 5 were considered significant, from 3.5 to 3.99 - less significant, equal to and lower than 3.4 - insignificant).

The data in Table 3 show that the value of land as of an investment object is mainly affected by economic and political determinants. With reference to the data of the Bank of Lithuania (2017), the inflation rate in Lithuania in 2017 amounted to $3.7 \%$. In 2018 , it is predicted to decrease to $2.6 \%$. The growth in the wage level $(+6.5 \%$ in 2017, and $5.7 \%$ in 2018) exceeds the increase in labour productivity. As a result, increasing labour costs have a magnifying effect on the price rate. Higher income of the population also puts pressure on prices due to the growth of domestic demand. Over the period from 2016 to 2017, the country's real GDP increased by $3.3 \%$; in 2018, it is predicted to increase by $2.8 \%$. The country's main macroeconomic indicators show that Lithuania is undergoing the period of economic growth. With reference to the Bank of Lithuania (2017), the growth will continue in 2018, but will slow down in 2019 due to the impact of such risks as the US geopolitical conflicts, Chinese credit cycle changes and unsustainable price rates in some global financial and asset markets.

The adoption of the Directive on Credit Agreements for Consumers Relating to Residential Immovable Property (or Housing Credit Directive) (2014) has established equal conditions of competition for bank and non-bank institutions. The newly-issued (as of July 1, 2017) the Republic of Lithuania Law on Real Estate Related Credit has also affected the behaviour of real estate investors.

Interdependence of financial markets (globalisation and innovativeness which manifest through the development of financial innovations and technologies), legal factors (legal regulation of property, regulation of the transfer of property rights, real esate taxation), the volume of mortgage loans, migration rate and governmental stability in

\footnotetext{
1 The values of Cronbach alpha were estimated by employing the SSPS software package.
} 
Table 3. The general determinants of the value of land by their significance.

\begin{tabular}{|c|c|c|c|c|c|}
\hline Significant determinants & Mean ranks & $\begin{array}{l}\text { Less significant } \\
\text { determinants }\end{array}$ & Mean ranks & Insignificant determinants & Mean ranks \\
\hline $\begin{array}{l}\text { 1. The stage of an } \\
\text { economic cycle }\end{array}$ & 5 & 1. Governmental stability & 3.80 & 1. Sustainability & 3.4 \\
\hline 2. Inflation rate & 4.40 & 2. Migration rate & 3.8 & 2. FDI flows & 3.4 \\
\hline $\begin{array}{l}\text { 3. Changes in the credit } \\
\text { market }\end{array}$ & 4.20 & $\begin{array}{l}\text { 3. The impact of financial } \\
\text { institutions }\end{array}$ & 3.8 & 3. Land taxes & 3.4 \\
\hline 4. GDP rate & 4.00 & 4. Real estate taxes & 3.8 & $\begin{array}{l}\text { 4. Construction permit } \\
\text { control }\end{array}$ & 3.4 \\
\hline 5. Wage level & 4.00 & 5. Globalisation & 3.6 & $\begin{array}{l}\text { 5. The term of construction } \\
\text { permit issuance }\end{array}$ & 3.4 \\
\hline 6. Governmental policies & 4.00 & 6. Innovativeness & 3.6 & $\begin{array}{l}\text { 6. The number of finished } \\
\text { buildings }\end{array}$ & 3.2 \\
\hline & & $\begin{array}{l}\text { 7. Legal regulation of } \\
\text { property }\end{array}$ & 3.6 & $\begin{array}{l}\text { 7. The level of population's } \\
\text { education }\end{array}$ & 3.2 \\
\hline & & $\begin{array}{l}\text { 8. Legal regulation of the } \\
\text { transfer of property rights }\end{array}$ & 3.6 & 8. Birth rate & 3.2 \\
\hline & & $\begin{array}{l}\text { 9. The volume of mortgage } \\
\text { loans }\end{array}$ & 3.6 & $\begin{array}{l}\text { 9. The impact of political } \\
\text { parties }\end{array}$ & 3.2 \\
\hline & & & & 10. Unemployment rate & 3.2 \\
\hline & & & & 11. Employment rate & 3.0 \\
\hline & & & & 12. Poverty rate & 3.0 \\
\hline & & & & 13. Population's age & 3.0 \\
\hline & & & & $\begin{array}{l}\text { 14. Total useful floor area } \\
\text { of finished buildings }\end{array}$ & 3.0 \\
\hline & & & & $\begin{array}{l}\text { 15. The level of social } \\
\text { protection }\end{array}$ & 2.2 \\
\hline & & & & $\begin{array}{l}\text { 16. The number of } \\
\text { marriages }\end{array}$ & 1.80 \\
\hline
\end{tabular}

the country are attributable to the group of less significant determinants. According to the experts, the largest part of institutional, demographic and construction sector determinants are insignificant, which proposes that the value of land is mainly determined by economic, political, legal factors and interdependence of financial markets.

In order to verify the links between the value of arable land and such strongly correlated determinants as migration rate, unemployment rate and demographic aging coefficient (the changes in the population's age characterised by an increase in the number of elderly people or a decrease in the number of young people) or wage rate and at-risk-to-povery rate, we estimated Pearson's correlation coefficients and developed the equations of the multiple regression for different Lithuanian districts for the period from 2011 to 2016 (see Appendix). The choice of the period under consideration was determined by the availability of the statistical data for Lithuanian districts. It should be noted that the data on at-risk-to-poverty rate were available only for age groups, cities/villages and the division of the capital and central/western regions of the country, but unavailable for particular districts, which caused limitations of the research.

The estimations have revealed that wage growth led to an increase in the value of arable land in all Lithuanian districts over the period under consideration. Unemployment rate negatively affected the prices of arable land in Kaunas, Marijampolè, Panevėžys, Šiauliai, Utena and Vilnius districts ( 6 out of 10 districts), while the values of the demographic aging coefficient positively correlated to the prices of arable land in all Lithuanian districts apart from Vilnius district. It can be concluded that the mathematical estimations confirmed the results of the expert evaluation stipulating that wage rate has a significant impact on the prices of arable land, but differed from the experts' opinion on the impact of unemployment rate and demographic aging coefficient. In addition, the experts assessed the general situation in the country without consideration of the conditions in particular districts, while the mathematical estimations did consider the districts because the prices of arable land may significantly vary depending on a district (for instance, as of 2016, the price of arable land amounted to 2787 Eur/ha in Vilnius district, 1835.39 Eur/ ha in Utenos district, and so forth).

Economic factors are extremely important as they determine not only the value of land, but also the cycles of the entire real estate market. They indicate where and when investors may choose the most favourable options of investment. Land in developing economies can be a cheap and attractive investment, but higher profits earned from 
real estate transactions require longer terms. In growing economies, investors are likely to afford more expensive real estate objects and land plots.

Political factors have a significant impact on the value of land when the governments are changing, the political situation in the country is not stable, the legal framework is confusing and land investors are charged unreasonably high taxes.

The results of the expert evaluation have also revealed that the most influential microeconomic determinants include land plot location, market prices of other real estate objects, expectations of future cash flows, expectations of real estate price changes and an investor's rationality/ irrationality (with mean ranks equal to 5). The value of land is slightly less affected by land plot size, financial expediency of the invesment in a land plot, the level of regional economic development, the impact of an investor's environment (with mean ranks equal to 4.8), the factors of possibly best land usage (land's suitability for agricultural activities, attractiveness for construction, etc.) (with mean rank equal to 4.6), present decision-making by following past trends (with mean rank equal to 4.4), real estate rental rates, and correspondence between and an object's characteristics and an investor's taste and needs (with mean ranks equal to 4).

Such determinants as land quality, maintenance costs and neigboring natural environment (with mean ranks equal to 3.6) were recognized as less significant, while current condition of a land plot and pollution (with mean ranks equal to 3.2) - as insignificant. The results of the expert evaluation lead to the conclusion that microenvironmental determinants more significantly affect the value of land than macroenvironmental determinants because vast majority of microenvironmental determinants (except current condition of a land plot and pollution) were recognized as significant.

The authors of this article are of the opinion that classification of land into the categories of land and arable land is one of the factors that determines the differences in the price and popularity of these two kinds of land among investors. The prices of arable land largely depend on a region (two opposites in Lithuania in this regard are Aukštaitija region and Žemaitija region), fertility as well as EU subsidies for land owners and renters. In case arable land is located in an infertile region which, however, is characterised by a rich landscape, the land can be included into the list of tourism-favourable or heritage territories. In the latter case, changing of the purpose of land may provide more opportunities for investors to earn the return on their investment. The value of commercial and residential land plots is significantly affected by their geographical location, landscape, population, employment rate, municipal policies and infrastructural development.

In Lithuania, arable land is available to foreign investors in accordance with certain legal provisions. Over the period of the last ten years, this land has been attractive to Scandinavian investors - a part of them have exploited an opportunity to acquire land plots for the establishment of businesses, factories, farms, etc. As previously mentioned, the prices of arable land partly depend on the EU subsidisation which causes the prices to increase or decrease.

The main differences and opportunities to invest in arable land in local and global context depend on the conditions of institutional regulation in every state. As due to the CAP policies, the article is more oriented to the context of the EU states (Lithuania is a member of the EU), we will present the peculiarities of the investment in arable land in the EU. The presumption that land transactions (purchase-sale) and well-functioning land market play significant roles in economic development is supported by the following arguments: first, land transactions provide the access to land to the most efficient farmers who currently have less land than they would need to; second, land transactions allow land exchange and so contribute to the development of the non-agricultural labour market; third, they facilitate the use of land as collateral when accessing credit markets (Ciaian, Kancs, Swinnen, Herck, \& Vranken, 2012). The investment in arable land in the EU is commonly made with a view to renting the land to farmers.

In a local context, there may exist quantitative regulations. In most EU member states, land transactions are comparatively free and unrestricted to either natural or juridical persons. Nevertheless, some authorities, for instance, France, Germany or Sweden, require the approval of governmental institutions, while Lithuania and Hungary have such restrictions as possession of the maximum quantities of land allowed. In France, SAFER (the Sociétés d'Aménagement Foncier et d' Etablissement Rural) monitors land transactions and prohibits arable land purchasessales for speculative purposes. In Germany, the sales of an arable land plot larger than the minimum setpoint have to be approved by Genehmigungsberhörde. In addition, in the cases of land consolidation, a neighbour-farmer has the right of land purchase priority against an external purchaser. In Sweden, land can be acquired without meeting such standards as education or previous experience in the agricultural sector. For acquisition of land plots in less populated areas, potential land buyers need to submit special permissions with indication of their education, previous experience in land management or in rare cases the intentions to live on the land to be acquired. In most countries, renters have the right of priority to acquire the arable land which is the object of the rent (Germany, Belgium, Italy, France).

When assessing the situation in a global context, it should be noted that there are no restrictions for foreigners to acquire arable land in the old EU member states (Belgium, Germany, Ireland, Greece, Spain, France, Italy, the Netherlands, Finland, Sweden and the UK), unless the plots of interest are situated in strategically sensitive areas. For instance, in Greece, foreigners cannot own property rights to the land situated in border areas without a special pre-approval of the Ministry of Defence. However, in new 
EU member states (Belgium, Czech Republic, Estonia, Latvia, Lithuania, Romania, Slovakia) foreigners could not acquire arable land during the seven-year transition period, in Poland - during the twelve-year transition period. In the above-mentioned new EU member states, foreigners up-to-date have a special legal status and must comply with particular legal norms to acquire arable land.

The new EU member states do not impose any land price regulations, while the governments of the old EU member state impose price regulations on agricultural land markets.

Taxation is another factor that may significantly affect a decision to invest in land as taxes have a direct impact on land demand and supply. Two following types of taxes are currently being levied on land in the EU: 1) land transaction taxes (capital gains tax for sales and registration tax for purchases), and 2) usage (real estate) tax. Overall, land transaction taxes are heterogeneous across the member states, ranging from $1 \%$ for low-value land in the UK to $18 \%$ for high-value land in Italy. Usage (real estate) taxes are also heterogeneous across the member states, ranging from a tax rate of $0 \%$ on farmland to over $15 \%$ in some of the southern European countries. In Finland, Greece, Ireland, the Netherlands, Sweden and the UK, there is no usage tax on agricultural land. Looking from the perspective of the investment in non-arable land, we should state that the basic motive of the investment in non-arable land in both a global and a local context is the development of the real estate infrastructure (i.e. a strive to earn higher profits in the future). Land sales and land keeping taxes are different. For instance, in Lithuania, a 15\% income tax rate is imposed on land sales, while land keeping taxes range from 0.1 to $4 \%$. Taxes rates (e.g., VAT, income tax rates) depend on the type of a land transaction (inheritance, gift, acquisition) and the purchase-sales price difference.

\section{Conclusions}

The results of the expert interviews and expert evaluation have dislosed that land is considered to be a safe investment (the asset which retains its value). Land price rise is stable, and over the period under research it exceeded the rise of other asset prices. Land investors in Lithuania are driven by the following motives: 1) speculative aims to earn a difference from the purchase price; 2 ) the aims to earn from the rent of arable land; 3) the aims to protect the investment from inflation.

The value of arable land in Lithuania is undoubtedly lower than the EU average. Soaring global population is consuming increasingly larger quantities of agricultural production, which, minding the fact that land is a scarce resource and cannot be multiplied, allows to expect the further land price growth.

The results of the expert evaluation have confirmed the theoretical presumptions that the value of land is mainly determined by economic factors, although the changes in land prices are not neccesarily linked to the changes in the land market. When an investor is choosing a land plot, he/she also considers microenvironmental factors, for instance, availability of land plots in developing regions with the infrastructures being improved. Land plots with unchanged purposes but without infrastructures (for instance, arable land) are not popular among investors, so their prices remain stable. Land productivity (productive land is in higher demand) and the area of a land plot (larger areas are more expensive) are the most influential microenvironmental determinants of the value of arable land. The latter is also significantly affected by such general determinants as the impact of legal restrictions and recent tightenings of laws stipulating that arable land can be purchased by the third party only in case a co-owner, renter or borrower refuses to purchase it. What is more, it should not be overlooked that the supply of arable land tends to decline, and the reserve of vacant land plots in Lithuania is only temporary.

Further studies on the topic under consideration could be related to the changes in the value of arable land after the reduction (termination) of the EU subsidy flows. They also may focus on trends of the investment in arable land in the Baltic States or other EU member states.

\section{References}

Augustinaitis, A., Rudzkienè, V., Petrauskas, R. A., Dagytė, I., Martinaityte, E., Leichteris, E., Malinauskienė, E., Višnevska, V., \& Žilionienè, I. (2009). Lietuvos e. valdžios gairès: ateities jॄžvalgu tyrimas [E-Government guidelines of the Republic of Lithuania: research study of future insights]. Vilnius: Mykolo Romerio universiteto Leidybos centras.

Bergdolt, C., \& Mittal, A. (2012). Betting on world agriculture. Oakland: Oakland Institute Publishing. Retrieved from http:// www.oaklandinstitute.org/betting-world-agriculture-us-private-equity-managers-eyeagricultural-returns

Buxton, A., Campanale, M., \& Cotula, L. (2012). Farms and funds: investment funds in the global land rush. IIED Briefing Papers, The International Institute for Environment and Development (IIED), Jan 2012 - IIED. Retrieved from http:// pubs.iied.org/17121IIED/

Ciaian, P., Kancs, d’A., Swinnen, J., Herck, K., \& Vranken, L. (2012). Sales market regulations for agricultural land in EU members states and candidate countries (Working paper, No. 14).

Directive 2014/17/EU. (2014). Directive of the European Parliament and of the Council of 4 February 2014 on credit agreements for consumers relating to residential immovable property and amending Directives 2008/48/EC and 2013/36/EU and Regulation (EU) No 1093/2010. Retrieved from https://eur-lex. europa.eu/legal-content/EN/TXT/?uri=CELEX:32014L0017

Dong, Z., \& Sing, T. F. (2017). Developers' heterogeneity and real estate development timing options. Journal of Property Investment \& Finance, 35(5), 472-488. https://doi.org/10.1108/JPIF-07-2016-0058

Eberlin, E. (2017). Strategies and risks to consider when buying land. Retrieved from https://www.thebalance.com/strategiesand-risks-to-buy-land-4135603

Enemark, S. (2001). Land administration infrastructures for sustainable development. Property Management, 19(5), 366-383. https://doi.org/10.1108/02637470110410194 
Faulkner, D. (2016). The Chinese real estate market: development, regulation and investment. Journal of Property Investment \& Finance, 34(6), 670-671.

https://doi.org/10.1108/JPIF-07-2016-0057

Figari, F., Paulus, A., Sutherland, H., Tsakloglou, P., Verbist, G., \& Zantomio, F. (2012). Taxing home ownership: distributional effects of including net imputed rent in taxable income. Retrieved from http://ftp.iza.org/dp6493.pdf

French, N. (2015). Real estate investment: a strategic approach. Journal of Property Investment \& Finance, 33(6), 594-595. https://doi.org/10.1108/JPIF-07-2015-0055

Gholipour Fereidouni, H., \& Ariffin Masron, T. (2013). Real estate market factors and foreign real estate investment. Journal of Economic Studies, 40(4), 448-468. https://doi.org/10.1108/JES-05-2011-0066

Grant, T. (2016). Is raw land a good investment? Retrieved from http://budgeting.thenest.com/raw-land-good-investment-21604.html

Griggs, J., \& Kemp, P. A. (2012). Housing allowances as income support: comparing European welfare regimes. International Journal of Housing Policy, 12(4), 391-412. https://doi.org/10.1080/14616718.2012.711987

Gunnoe, A. (2014). The political economy of institutional landownership: neorentier society and the financialization of land. Rural Sociology, 79(4), 478-504. https://doi.org/10.1111/ruso.12045

Gunnoe, A., \& Gellert, P. (2011). Financialization, shareholder value, and the transformation of timberland ownership in the US. Critical Sociology, 37(3), 265-284. https://doi.org/10.1177/0896920510378764

Hegedüs, J., Lux, M., \& Sunega, P. (2011). Decline and depression: the impact of the global economic crisis on housing markets in two post-socialist states. Journal of Housing and the Built Environment, 26(3), 315-333. https://doi.org/10.1007/s10901-011-9228-7

Hin, K., Ho, D., \& Addae-Dapaah, K. (2014). Real estate market cyclical dynamics: the prime office sectors of Kuala Lumpur, Singapore and Hong Kong. International Journal of Managerial Finance, 10(2), 241-262.

https://doi.org/10.1108/IJMF-10-2013-0108

Kemp, P. (2007). Housing allowances in comparative perspective. Bristol: The Policy Press. https://doi.org/10.1332/policypress/9781861347541.001.0001

Knuth, S. E. (2015). Global finance and the land grab: mapping twenty-first century strategies. Canadian Journal of Development Studies, 36(2), 163-178. https://doi.org/10.1080/02255189.2015.1046373

Makridakis, S., Wheelwright, S. C., \& Hyndman, R. J. (1998). Forecasting: methods and applications. New York: John Wiley \& Sons.

Nunnally, J. C., \& Bernstein, I. H. (1994). Psychometric theory (3rd ed.). New York: McGraw-Hill.
Oxley, M., \& Haffner, M. (2010). Housing taxation and subsidies: international comparisons and the options for reform. Retrieved from https://www.jrf.org.uk/sites/files/jrf/housingtaxation-systems-full.pdf

Patterson, G. A. (2013). Investment in the global real estate market. In H. Fung \& Y. Tse (Eds.). International Financial Markets: (Frontiers of Economics and Globalization) (pp. 69-89). https://doi.org/10.1108/S1574-8715(2013)0000013009

Rosenberg, M. (2017). Current world population. Retrieved from https://www.thoughtco.com/current-world-population- 1435270

Scanlon, K., \& Elsinga, M. (2014). Policy changes affecting housing and mortgage markets: how governments in the UK and the Netherlands responded to the GFC. Journal of Housing and the Built Environment, 29(2), 335-360. https://doi.org/10.1007/s10901-013-9390-1

Squires, G., Hutchinson, N., Adair, A., Berry, J., McGreal, S., \& Organ, S. (2016). Innovative real estate development finance - evidence from Europe. Journal of Financial Management of Property and Construction, 21(1), 54-72. http://dx.doi.org/10.1108/JFMPC-09-2015-0036

The Bank of Lithuania. (2017). Lietuvos ekonomikos apžvalga: 2017 m. gruodis [Review of Lithuanian economics: December 2017]. Retrieved from https://www.lb.lt/uploads/ documents/files/musu-veikla/ekonomikos-analize-prognozes/2017_12_19_LT_ekonomikos_raida_ir_perspektyvos_ VIESAS_PRISTATYMAS_LT.pdf

The Parliament of the Republic of Lithuania. (2017). The Republic of Lithuania Law on Real Estate Related Credit. Retrieved from https://www.e-tar.lt/portal/lt/legalAct/ea8fee50ac9311e6b844fof29024f5ac

The Word Bank. (2018). Arable land (hectares per person). Retrieved from https://data.worldbank.org/indicator/AG.LND. ARBL.HA.PC

Tiwari, P., \& White, M. (2014). Real estate finance in the new economy. New Jersey: Wiley-Blackwell.

https://doi.org/10.1002/9781118836651

van der Heijden, H., Dol, K., \& Oxley, M. (2011). Western European housing systems and the impact of the international financial crisis. Journal of Housing and the Built Environment, 26(3), 295-313. https://doi.org/10.1007/s10901-011-9230-0

Williams, S. (2013a). The truth about land investing: 15 warning signs to look for when buying vacant land. Retrieved from: https://retipster.com/truthaboutlandinvesting/

Williams, S. (2013b). 10 rock-solid reasons why you should be investing in land. Retrieved from https://retipster.com/landinvesting/

Wyman, D., Seldin, M., \& Worzala, E. (2011). A new paradigm for real estate valuation? Journal of Property Investment \& Finance, 29(4/5), 341-358. https://doi.org/10.1108/14635781111150286 


\section{Appendix}

Table A1. Interdependencies between the prices of arable land and gross wages, net migration, unemployment rate and demographic aging coefficient in Lithuanian districts over the period 2011-2016

\begin{tabular}{|c|c|c|c|c|}
\hline No. & District & Pearson's correlation coefficient & Regression equation & Model reliability criteria \\
\hline 1. & $\begin{array}{l}\text { Alytus } \\
\text { district }\end{array}$ & $\begin{array}{l}\text { Gross wages } r=0.908(p=0.012) \\
\text { Demographic aging coefficient } r= \\
0.916(p=0.010)\end{array}$ & $\begin{array}{l}\text { Price of arable land Alytus district }=2.471^{\star} \mathrm{X}_{\text {gross wages }} \\
\text { When gross wages increase by one euro, the } \\
\text { price of arable land in Alytus region increases by } \\
2.471 \mathrm{EUR} / \text { ha. }\end{array}$ & $\mathrm{R}^{2}=0.879$, sig. $=0.002$ \\
\hline 2. & $\begin{array}{l}\text { Kaunas } \\
\text { district }\end{array}$ & $\begin{array}{l}\text { Unemployment rate } r=-0.900 \\
(p=0.015) \\
\text { Gross wages } r=0.913(p=0.011) \\
\text { Demographic aging coefficient } \\
\mathrm{r}=0.893(\mathrm{p}=0.016)\end{array}$ & $\begin{array}{l}\text { Price of arable land } \mathrm{K}_{\text {Kaunas district }}=4.315^{\star} \mathrm{X}_{\text {gross wages }} \\
\text { When gross wages increase by one euro, the price } \\
\text { of arable land in Kaunas district increases by } \\
4.315 \text { EUR/ha. }\end{array}$ & $\mathrm{R}^{2}=0.951$, sig. $=0.000$ \\
\hline 3. & $\begin{array}{l}\text { Klaipeda } \\
\text { district }\end{array}$ & $\begin{array}{l}\text { Gross wages } r=0.870(p=0.024) \\
\text { Demographic aging coefficient } \\
\mathrm{r}=0.870(\mathrm{p}=0.024)\end{array}$ & $\begin{array}{l}\text { Price of arable land } \text { Klaipeda district }=3.206^{*} \mathrm{X}_{\text {gross wages }} \\
\text { When gross wages increase by one euro, the price } \\
\text { of arable land in Klaipeda district increases by } \\
\text { 3.206 EUR/ha. }\end{array}$ & $\mathrm{R}^{2}=0.884$, sig. $=0.002$ \\
\hline 4. & $\begin{array}{l}\text { Marijam- } \\
\text { polè dis- } \\
\text { trict }\end{array}$ & $\begin{array}{l}\text { Unemployment rate } r=-0.860 \\
(p=0.028) \\
\text { Gross wages } r=0.957(p=0.003) \\
\text { Demographic aging coefficient } \\
r=0.965(p=0.002)\end{array}$ & $\begin{array}{l}\text { Price of arable land }{ }_{\text {Marijampole district }}= \\
28.144^{\star} \mathrm{X}_{\text {gross wages }}-100.907^{\star} \mathrm{X}_{\text {demographic aging coefficient }} \\
\text { When gross wages increase by one euro, the price } \\
\text { of arable land in Marijampole district increases } \\
\text { by } 28.144 \text { EUR/ha in case other conditions } \\
\text { remain unchanged. When the demographic } \\
\text { aging coefficient decreases by a unit, the price of } \\
\text { arable land in Marijampole district decreases by } \\
100.907 \text { EUR/ha. }\end{array}$ & $\mathrm{R}^{2}=0.981$, sig. $=0.000$ \\
\hline 5. & $\begin{array}{l}\text { Panevėžys } \\
\text { district }\end{array}$ & $\begin{array}{l}\text { Unemployment rate } r=-0.959 \\
(\mathrm{p}=0.002) \\
\text { Gross wages } \mathrm{r}=0.967(\mathrm{p}=0.002) \\
\text { Demographic aging coefficient } \\
\mathrm{r}=0.989(\mathrm{p}=0.000)\end{array}$ & $\begin{array}{l}\text { Price of arable land }{ }_{\text {Panevezzys district }}=24.488^{\star} \mathrm{X}_{\text {gross }} \\
\text { wages }-79.079^{\star} \mathrm{X}_{\text {demographic aging coefficient }} \\
\text { When gross wages increase by one euro, the price } \\
\text { of arable land in Panevėžys district increases } \\
\text { by } 24.488 \mathrm{EUR} / \mathrm{ha} \text { in case other conditions } \\
\text { remain unchanged. When the demographic } \\
\text { aging coefficient decreases by a unit, the price } \\
\text { of arable land in Panevežzys district decreases by } \\
79.079 \mathrm{EUR} / \mathrm{ha} \text {. }\end{array}$ & $\mathrm{R}^{2}=0.987$, sig. $=0.000$ \\
\hline 6. & $\begin{array}{l}\text { Šiauliai } \\
\text { district }\end{array}$ & $\begin{array}{l}\text { Unemployment rate } r=-0.937 \\
(\mathrm{p}=0.006) \\
\text { Gross wages } \mathrm{r}=0.830(\mathrm{p}=0.0041) \\
\text { Demographic aging coefficient } \\
\mathrm{r}=0.921(\mathrm{p}=0.009)\end{array}$ & 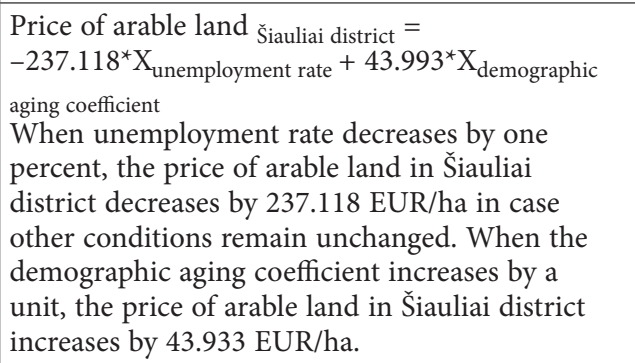 & $\mathrm{R}^{2}=0.988$, sig. $=0.000$ \\
\hline 7. & $\begin{array}{l}\text { Tauragè } \\
\text { district }\end{array}$ & $\begin{array}{l}\text { Gross wages } r=0.948(p=0.004) \\
\text { Demographic aging coefficient } \\
r=0.976(p=0.001)\end{array}$ & $\begin{array}{l}\text { Price of arable land } \text { Taurage district } \\
\text { wages }-53.438^{\star} \mathrm{X}_{\text {demographic aging coefficient }} \\
\text { When gross wages increase by one euro, the } \\
\text { price of arable land in Taurage district increases } \\
\text { by } 16.472 \mathrm{EUR} / \mathrm{ha} \text { in case other conditions } \\
\text { remain unchanged. When the demographic aging } \\
\text { coefficient decreases by a unit, the price of arable } \\
\text { land in Taurage district decreases by } \\
53.438 \text { EUR/ha. }\end{array}$ & $\mathrm{R}^{2}=0.979$, sig. $=0.000$ \\
\hline
\end{tabular}


End of Table A1

\begin{tabular}{|c|c|c|c|c|}
\hline No. & District & Pearson's correlation coefficient & Regression equation & Model reliability criteria \\
\hline 8. & $\begin{array}{l}\text { Telšiai } \\
\text { district }\end{array}$ & $\begin{array}{l}\text { Gross wages } r=0.956(p=0.003) \\
\text { Demographic aging coefficient } \\
r=0.963(p=0.002)\end{array}$ & $\begin{array}{l}\text { Price of arable land }{ }_{\text {Telšiai district }}= \\
18.814^{\star} \mathrm{X}_{\text {gross wages }}-84.619^{*} \mathrm{X}_{\text {demographic aging }} \\
\text { coefficient } \\
\text { When gross wages increase by one euro, the } \\
\text { price of arable land in Telšiai district increases by } \\
18.814 \text { EUR/ha in case other conditions remain } \\
\text { unchanged. When demographic aging coefficient } \\
\text { decreases by a unit, the price of arable land in } \\
\text { Telšiai district decreases by } 84.619 \text { EUR/ha. }\end{array}$ & $\mathrm{R}^{2}=0.987$, sig. $=0.000$ \\
\hline 9. & $\begin{array}{l}\text { Utena } \\
\text { district }\end{array}$ & $\begin{array}{l}\text { Unemployment rate } r=-0.947 \\
(p=0.004) \\
\text { Gross wages } r=0.964(p=0.002) \\
\text { Demographic aging coefficient } \\
r=0.956(p=0.003)\end{array}$ & $\begin{array}{l}\text { Price of arable land }{ }_{\text {Utena district }}=17.280{ }^{*} \mathrm{X}_{\text {gross }} \\
\text { wages }-49.543^{*} \mathrm{X}_{\text {demographic aging coefficient }} \\
\text { When gross wages increase by one euro the } \\
\text { price of arable land in Utena district increases by } \\
17.280 \mathrm{EUR} / \mathrm{ha} \text { in case other conditions remain } \\
\text { unchanged. When demographic aging coefficient } \\
\text { decreases by a unit, the price of arable land in } \\
\text { Utena district decreases by } 49.543 \mathrm{EUR} / \mathrm{ha} \text {. }\end{array}$ & $\mathrm{R}^{2}=0.982$, sig. $=0.000$ \\
\hline 10. & $\begin{array}{l}\text { Vilnius } \\
\text { district }\end{array}$ & $\begin{array}{l}\text { Unemployment rate } r=-0.873 \\
(p=0.023) \\
\text { Gross wages } r=0.962(p=0.002)\end{array}$ & $\begin{array}{l}\text { Price of arable land }{ }_{\text {Vilnius district }}= \\
-6562.057+10.714^{*} \mathrm{X}_{\text {gross wages }} \\
\text { When gross wages increase by one euro, the price } \\
\text { of arable land in Vilnius district increases by } \\
10.714 \mathrm{EUR} / \mathrm{ha} \text {. }\end{array}$ & $\mathrm{R}^{2}=0.925$, sig. $=0.000$ \\
\hline
\end{tabular}

